\title{
The Design Path of State-owned Enterprise Equity Incentive Scheme
}

\author{
Wang $\operatorname{Han}^{1,{ }^{*}} \mathrm{He} \mathrm{Wan}^{1}$ Gao Tong ${ }^{2}$ \\ ${ }^{1}$ State Grid Energy Research Institute Co.,Ltd., Beijing, 102209, China \\ ${ }^{2}$ State Grid Changchun Power Supply Company, Changchun, 130021, China \\ * Corresponding author's e-mail: wanghan@sgeri.sgcc.com.cn
}

\begin{abstract}
Equity incentives are an important medium and long-term incentive method for state-controlled listed companies and state-owned technological enterprises. This article starts from the related policies of state-owned enterprises' equity incentives and corporate practices, and deeply explores the design path of state-owned enterprises' equity incentive programs. It describes in detail the operation steps of state-owned enterprise equity incentives from the aspects of determining incentive objects, determining the number of shares granted, determining the grant/exercise price, determining the source of equity, determining the conditions of grant/exercise, and determining the exit and default mechanism. It also reminds the risks that state-owned enterprises may face in equity incentives, and provides effective support for state-owned enterprises to implement equity incentives.
\end{abstract}

Keywords: Equity Incentive, Medium and Long-term incentives, State-owned Enterprise

\section{INTRODUCTION}

The operating steps of equity incentives for statecontrolled listed companies and state-owned technology companies are basically the same. The operation of equity incentives for state-owned enterprises is divided into 6 steps, namely, "determining the target, quantity, price, source, condition, and withdrawal". The specific operations of each step must meet the requirements of relevant policies and meet the needs of enterprise development.

\section{OPERATIONAL STEPS OF STATE- OWNED ENTERPRISE EQUITY INCENTIVE}

\subsection{Determine the Incentive Object}

The first is to determine the incentive objects within the scope allowed by the policy. Relevant policies have clearly defined the scope of equity incentives for listed companies and technology companies. It clearly stated the focus of equity incentives and the objects that cannot be included in the scope of equity incentives.[1]

The second is to select incentive objects through job value evaluation. The selection of equity incentive objects is generally based on the position as the division standard, that is, the personnel in the positions that have a key core role in the development of the enterprise are regarded as the incentive objects. In the selection of positions, the value of each position is generally determined by the evaluation of the position value, and the positions that have a higher contribution to the development of the company are designated according to the needs of the company.

The third is the natural departure time of the incentive objects should be later than the exercise time. In order to limit the short-term behavior of incentive objects, equity incentives generally have an exercise period or an unlock period. In particular, the unlocking period of restricted stocks and stock options will be as long as 3-5 years. Therefore, when determining the incentive object, the natural departure time of the personnel within the above range should be considered in advance. Generally, it is necessary to exclude employees who are about to retire within the validity period, and carefully consider those whose labor contracts are about to expire.[2]

\subsection{Determine the Number of Shares Granted}

Relevant policies have made clear regulations and restrictions on the total amount of equity that can be granted by various enterprises and individual quotas. 
Companies can determine the number of equity to be granted in accordance with policy restrictions and combined with company needs. Generally speaking, the size of a company is inversely proportional to the number of shares granted. That is to say, the larger the company, the lower the proportion of granted equity, so as to avoid the total amount of incentives and the excessive dispersion of equity. In addition, companies can reverse the future value of equity. That is, according to the comparison of the market price when the incentive equity expires and the expected salary of the incentive object, the number of equity granted is determined.

As far as the state-controlled listed company is concerned, it may also consider reserving part of the equity when determining the number of equity to be granted. The document "Memorandum No. 1, No. 2, and No. 3 of the Securities Regulatory Commission on Equity Incentive Relevant Matters" made detailed provisions on this. "The company shall not reserve shares in principle if there is no special reason. If it is really necessary to reserve shares, the reserve ratio shall not exceed $10 \%$ of the amount of equity to be granted in this equity incentive plan." Therefore, companies can reserve part of the equity in order to include more qualified employees in the scope of equity incentives based on the results of the talent inventory, the growth of the number of employees over the years and the promotion.[3]

\subsection{Determine the Grant/Exercise Price}

According to relevant policies and regulations, the exercise price of equity incentives for state-controlled listed companies is determined in principle with reference to the fair market price. The exercise price of stock options and stock appreciation rights shall be determined according to the fair market price, and the grant price of restricted stock shall be determined not less than $50 \%$ of the fair market price. When determining the exercise price, it should take into account factors such as the maturity of scientific and technological achievements and their transformation, the profitability of the company in the next 5 years, and the number of total equity to be granted by the company, and it shall not be lower than that approved or filed when the stock option incentive plan was formulated. The appraised value per share.

\subsection{Determine the Source of Equity}

The source of the underlying stocks required for the implementation of the equity incentive plan is generally based on the issuance of shares to the incentive object (capital increase and share expansion) and the repurchase of the company's shares (share repurchase). Moreover, state-controlled listed companies shall not be paid by a single state-owned shareholder or quantify state-owned equity without compensation. State-owned technologybased enterprises can also transfer their equity held by existing shareholders to incentive objects in accordance with the law.[4]

The two common methods of capital increase and share repurchase have their advantages and disadvantages. The use of capital increase and share expansion can effectively avoid the occupation of the company's current cash flow, and the company's pressure is relatively small, but the original shareholder's equity ratio will be diluted to a certain extent. Although the share repurchase method can effectively avoid the payment of a single state-owned shareholder, the enterprise will bear greater pressure on cash flow. Enterprises should determine the source of incentive equity based on the current equity distribution and capital pressure.

\subsection{Confirm Grant/Exercise Conditions}

The conditions for granting/exercising equity incentives should be linked to the achievement of the company's goals and the achievement of the incentive targets' performance. Only when the performance of the company and the incentive objects meet the requirements, the incentive objects can exercise their rights. Companies can use profit growth rates, asset yields, and main business income growth rates as company performance indicators based on actual business development. Listed companies can also choose the company's market value, earnings per share, dividends per share, etc. Individual performance indicators are determined according to the company's strategic goals, overall performance indicators, and job functions.

In addition, companies must also formulate methods for dealing with equity when they cannot exercise their rights. When the performance of either or both of the company or the incentive object fails to meet the exercise conditions, the equity incentive subject of the current period shall not be exercised. Generally, the company will cancel this part of the equity incentive subject by the company or repurchase it at the original grant price, and try not to cause losses to the incentive object.

\subsection{Determine Exit and Default Mechanism}

There are generally two exit situations for equity incentives.

The first is that the incentive object has not yet obtained the equity, that is, loses the qualification to exercise. In this case, the employee does not yet have the status of a shareholder, and only needs to agree with the employee on the conditions for terminating the equity incentive agreement or prohibiting the exercise of rights.

The second is that the incentive object has acquired equity. At this point, the employee has the status of a shareholder, so the company can agree with the employee a certain amount of liquidated damages in accordance with the "Contract Law" and the "Company Law". 
With regard to the exit mechanism, the relevant regulations for state-owned technology-based enterprises and state-controlled listed companies are different. Among them, the state-controlled listed company requires that the corresponding provisions such as the acceleration and termination of the exercise of rights in the incentive plan be made in accordance with the law. For details, please refer to the following methods.

\subsubsection{Clear Exit Method}

The first is to exit directly. That is, when the incentive object has not exercised its rights, the company can directly withdraw the equity in accordance with the agreed conditions, without the cooperation of the incentive object and no cost. This method is generally applicable to employee resignation or faulty withdrawal.

The second is stock repurchase, that is, the company buys back the stocks previously granted to employees at a certain price. This is a relatively common exit method and is suitable for all types of equity incentives. However, if there are too many exits at one time, the company's finances will face greater pressure.

The third is the transfer of equity by employees, that is, the incentive object transfers their equity to a third party. This method requires prior agreement on the transfer conditions, the third party's selection method, and how to determine the right of first refusal if multiple people meet the conditions.

\subsubsection{Clear Exit Price}

State-controlled listed companies can generally determine the exit price based on the comprehensive calculation of the fair price of the stock.

State-owned technology-based enterprises have made clear provisions in the "Interim Measures on Equity and Dividend Incentives for State-owned Technology-based Enterprises".

The incentive objects of equity incentives shall not be transferred or donated within 5 years from the date of acquiring the equity. Special circumstances shall be handled according to the following regulations:

The first category is the dismissal or termination of the labor contract due to the employee's resignation or personal reasons. All equity acquired by employees shall be returned to the enterprise within six months. The part of his personal capital contribution shall be returned to me by the enterprise based on the net assets after the audit of the previous year.

In case of leaving the company due to public transfer, all the acquired equity shall be returned to the company within half a year. The part of its personal capital contribution shall be returned to employees by the company in accordance with the principle that the net asset calculation after the previous year's audit is higher than the actual capital contribution cost.[5]

In addition, on-the-job incentive objects shall not require the enterprise to withdraw the incentive equity for any reason.

\section{COMMON RISKS OF EQUITY INCENTIVES IN STATE-OWNED ENTERPRISES}

\subsection{The Shareholder identity and Rights and Interests of the Incentive Object}

After the implementation of equity (real share) incentives and the incentive objects exercise their rights, the incentive objects hold the company's equity and have the status of a company shareholder. According to Article 4 of the "Company Law of the People's Republic of China", "the shareholders of the company shall enjoy the rights of asset income, participate in major decisionmaking, and select managers in accordance with the law." Specifically, it includes inspection and reproduction rights, dividend rights and preemptive rights, voting rights, equity transfer rights, preemptive rights, etc. The voting rights of shareholders of a limited liability company may be separately stipulated in accordance with the company's articles of association. Except for the voting rights, which can be separately stipulated by the articles of association, the above rights belong to the inherent rights of shareholders.

In the process of implementing equity incentives, state-owned enterprises generally hope that the shareholders' rights owned by the incentive objects should not be too large, so as to avoid risks to the normal operation of the company. According to relevant laws and regulations, combined with the practical experience of other companies, the following methods can generally be adopted to avoid related risks.

The first is that the incentive object itself signs a statement of waiving shareholder rights. That is, in the statement, it is stated that the shareholder or rights of which shareholder is waived, and that it is voluntarily waived rather than forced to waive according to the wishes of others. However, this method may cause dissatisfaction among the motivated objects, thereby affecting the motivation effect.

The second is to specify the conditions for shareholders with voting rights in the company's articles of association, so that the incentive objects are excluded from the scope of shareholders with voting rights. It should be noted that the articles of association of the company need to be unanimously approved by the general meeting of shareholders, so it is best to complete the amendments to the articles of association before launching equity incentives. 
The third method is to adopt indirect shareholding, so that the incentive objects can indirectly hold equity through the establishment of a limited liability company or partnership shareholding platform. However, it should be noted that indirect shareholding units must not have horizontal competition or related transactions with the enterprise. This indirect method of holding shares allows employees not to directly become shareholders of the company, but to enjoy relevant rights and interests as shareholders of the shareholding platform, which better avoids the business risks of the company.

The fourth is to use stock appreciation rights or virtual equity to carry out incentives. Both of these incentive methods are cash-based incentive methods similar to equity incentive methods. In the incentive process, they are only based on equity value or stock price. The incentive object itself does not hold real shares, and naturally does not have the identity of a shareholder. This can fundamentally prevent the incentive objects from enjoying shareholder rights, and at the same time may have a negative impact on the incentive effect of some employees with higher demand for participating in the company's operations.

\subsection{Withdrawal and Default Mechanism}

Determining the exit and default mechanism is an important step that companies tend to ignore when formulating equity incentive plans.

On the one hand, it is necessary to avoid arguing with the company due to the absence of clear exit conditions and price regulations when employees must withdraw. On the other hand, it is necessary to prevent some incentive objects from maliciously harming the interests of the company and other incentive objects through the establishment of liability for breach of contract, thereby affecting the incentive effect.

\section{CONCLUSION}

As a medium and long-term incentive method commonly used by state-controlled listed companies and state-owned technological enterprises, equity incentives have relatively clear policy requirements and relatively rich implementation experience. It is necessary to clarify the relevant content during the design of the equity incentive plan and avoid corresponding risks in advance. The operating steps of the equity incentive plan include "determining the object, quantity, price, source, condition, and exit". In the implementation process, it is necessary to pay attention to that the incentive object will automatically have the identity and rights of shareholders, and the exit and default mechanism should be clearly defined in the plan.

\section{ACKNOWLEDGMENT}

This project is supported by the State Grid Corporation of China Technology Project "Research on Talent Supply and Demand Analysis Model and Supply Strategy Research Adapting to Company Strategy" (SGSC0000KXJS2000095).

\section{REFERENCES}

[1] She, W., Research on Equity Incentive Mechanism of State-owned Technology Enterprises, in: Petroleum Science and Technology Forum, vol.38, Beijing, China, 2019, pp. 6-11. DOI: 10.3969/j.issn.1002-302x.2019.03.002.

[2] Zhang, C., Research on State-owned Enterprise Equity Incentives under the Background of Deepening Reform, in: Accounting and Accounting Study, vol.30, Beijing, China, 2020, PP. 135-136. DOI: 10.3969/j.issn.1673-4734.2020.30.070.

[3] Sun, W., Research on Equity Incentives of Listed Companies, in: Accountants, vol.6, Beijing, China, 2017, pp. 5-6. DOI: 10.3969/j.issn.16726723.2017.06.002.

[4] Heng. X., Analysis of Equity Incentives of Listed Companies, in: Contemporary Economy, vol.13, 2009 , pp. 103-105. DOI: 10.3969/j.issn.10079378.2009.13.061.

[5] Liang, C., Analysis of the Equity Incentive Mechanism of Listed Companies in China, in: Economist, vol.1, 2020, pp. 125+128. DOI: 10.3969/j.issn.1004-4914.2020.01.052. 